Pace University

DigitalCommons@Pace

$1-1-1991$

\title{
Energy and Environmental Challenges for Developed and Developing Countries
}

Richard L. Ottinger

Elisabeth Haub School of Law at Pace University

Follow this and additional works at: https://digitalcommons.pace.edu/lawfaculty

Part of the Comparative and Foreign Law Commons, Energy and Utilities Law Commons, and the Environmental Law Commons

\section{Recommended Citation}

Richard L. Ottinger, Energy and Environmental Challenges for Developed and Developing Countries, 9 Pace Envtl. L. Rev. 55 (1991), http://digitalcommons.pace.edu/lawfaculty/249/.

This Article is brought to you for free and open access by the School of Law at DigitalCommons@Pace. It has been accepted for inclusion in Pace Law Faculty Publications by an authorized administrator of DigitalCommons@Pace. For more information, please contact dheller2@law.pace.edu. 


\section{PACE ENVIRONMENTAL LAW REVIEW}

\begin{tabular}{lll}
\hline Volume 9 & Fall 1991 & Number 1 \\
\hline
\end{tabular}

\section{Energy and Environmental Challenges For Developed and Developing Countries}

Keynote Address Presented at the United Nations Meeting on Energy and Environment in the Development Process, Beijing, June 6-12, 1991*

\section{Honorable Richard L. Ottinger**}

Energy for development utilizing traditional supply investments, estimated to cost $\$ 1.4$ - $\$ 4$ trillion through 2010, will be unaffordable both for recipients and lenders. The capital required, even if obtainable, would squeeze out capital for all other development requirements and would pose unacceptable environmental and cleanup costs. Upgrading existing energy supply systems would cost a fraction of new supply. Energy efficiency and environmentally benign renewables can at least halve new supply capital requirements and avoid their environmental costs. Least cost planning by lenders and recipients, on the basis of total system life cycle costs, for both energy and non-energy related investments, is essential. Regional centers are needed for energy efficiency

* The address appears as originally presented except for minor editorial changes.

** Professor of Law, Pace University School of Law; Former Chair, U.S. House of Representatives Subcommittee on Energy Conservation \& Power; LL.B. Harvard University; B.A. Cornell University. 
and renewable education, training, implementation and $O \&$ $M$ support and joint procurement. Significantly increased energy and environmental investments are critical.

\section{Introduction}

Meeting the energy needs of developing countries in the coming decades in a manner which fosters economic development and avoids environmental degradation is one of the world's foremost challenges. Meeting the energy needs for development in a manner which avoids environmental degradation is not just a concern of developing nations, which must feed, clothe, provide health care, educate, house, and find jobs for exploding populations. It is equally a challenge for developed countries, which will suffer environmental degradation, soaring fuel prices, loss of large potential developing country markets, debt forfeitures, and huge international security costs deriving from developing country instability, if the energy needs to fuel development are not soundly met.

The bad news is that a supply-oriented strategy which both accepts current projections of development energy demands and seeks to satisfy them based on acquiring capitalintensive technologies requiring imported fuels is doomed to failure. Developing countries will be unable to meet either their energy needs or the basic development needs of their people. To the extent that their energy needs are thus met, it will be at horrendous cost of capital desperately needed for economic and social improvement in non-energy sectors and with tragic environmental consequences to developing countries and to the world. ${ }^{1}$

The good news is that present energy trends can be altered to the advantage of both developed and developing countries. Indeed, for developed countries, investing in the energy needs of their developing neighbors represents their greatest opportunity for future economic growth and prosperity. The markets of industrialized countries are virtually satu-

1. Office of Technology Assessment, U.S. Congress, OTA-E-486, Energy in Developing Countries 10 (1991) [hereinafter OTA]. 
rated, while the potential markets in developing countries for the goods and services presently enjoyed by industrialized nations are virtually unlimited.

Let us start with some basic truths. To me, they seem self-evident. I will document them later.

*Energy requirements for creating minimally acceptable standards of living for existing populations in most of the developing countries far exceed the resources of those countries and the developed nations to meet them with traditional energy supply strategies.

${ }^{*}$ Population growth projections in most developing countries will require vast new energy services, even assuming the most aggressive population control efforts.

*The capital required to meet energy needs of developing countries through traditional energy supply investments is unattainable.

*The environmental costs, internally and to the world, of meeting those energy needs with traditional supply investments are unacceptable.

*If developed countries wish to avoid the consequences of failure to meet energy needs of developing countries (human devastation, environmental disasters, and insupportable costs of national security, rising fuel prices and environmental degradation), then they and the multilateral lending institutions will have to make exponentially greater and wiser energy investments in developing countries than they presently contemplate.

*Developed countries and the multilateral lending agencies are disproportionately investing in insupportable capital-intensive supply resources, and they are ignoring investment in affordable efficiency and renewable resources.

*Economic energy investment requires least-cost planning, performed both by investors and recipients. Determination of least cost strategies requires calculation of life cycle and system costs (including the costs of power to operate equipment financed) and environmental costs.

*Existing and projected energy conservation and renewable resource technologies permit environmentally acceptable development at a small fraction of the total life cycle system societal cost of current supply investment 
strategies.

*Introduction of these benign technologies will require far more than financing their local manufacture or acquisition. Removal of import impediments, price controls, and subsidies for inefficient equipment and unaffordable fuels is essential. Far greater sensitivity to local conditions and use of local materials, talents, and resources is required. Local policies are needed to promote sound investments. Local or regional institutions are required for training and managing installations. Indigenous or regional research, development, manufacturing, and purchasing facilities will need to be created.

These goals are achievable.

I would add two more fundamental truths, not generally thought of in an energy context:

*War is the worst waster of energy. In addition to resulting in deaths, it causes destruction of infrastructure and environmental devastation. The quest for energy is a major cause of war. Destruction of energy supplies has become a weapon of war. If just half of the resources now devoted to manufacture, purchase and operation of weaponry were devoted to development, the energy and development needs of the world could readily be met. A major world energy strategy must include strengthening the United Nations' ability to resolve international disputes by peaceful means and commencing United Nations action to limit the manufacture, sale, and deployment of armaments.

*"Poverty is the greatest polluter."

The challenge was well put by Amulya K.N. Reddy and Jose Goldemberg:

If current trends persist, in about 20 years the developing countries will consume as much energy as the industrialized countries do now. Yet their standard of living will lag

2. Amulya K. N. Reddy \& Jose Goldemberg, Energy for the Developing World, ScI. AM. 111, 116 (Sept. 1990) [hereinafter Reddy], quoting late Prime Minister of India, Indira Ghandi at the Stockholm Conference on the Environment. 
even farther behind than it does today. This failure of development is not the result of a simple lack of energy, as is widely supposed. Rather, the problem is that the energy is neither efficiently nor equitably consumed. If today's most energy-efficient technologies were adopted in developing countries, then only about one kilowatt per capita used continuously - roughly 10 percent more than is consumed now - would be sufficient to raise the average standard of living to the level enjoyed by Western Europe in the 1970 's. ${ }^{3}$

If one adds to their eloquent statement the environmental consequences of continuing trends, and the environmental enhancement of an energy efficient scenario, one gets a succinct picture of the challenges and opportunities which lie before us.

Let us start with a number of examples, beginning perhaps in our host country of China which in many respects has become a leader in promoting energy efficiency. In 1980, China decided to distribute refrigerators throughout the capital city of Beijing. It did so with resounding success, supplying refrigerators to over $60 \%$ of Beijing households by 1990 , where only $6 \%$ had them in 1980 . The reconditioned refrigerators from Japanese factories were thought to be cheap. They were not cheap, however, when the costs of the electric power supply necessary to run these very inefficient machines became apparent. In fact, the purchase and supply of inefficient equipment cost more than three times what would have been the cost of supplying the most efficient refrigerators on the world market today. ${ }^{4}$ I should add that there are many success stories from our host country, most notably the massive program to achieve energy conservation in industry implemented in 1981. The funds China made available for conser-

\section{Id. at 1 .}

4. Testimony presented by Michael Totten, International Institute for Energy Conservation, before the Subcommittee on International Development, Finance, Trade and Monetary Policy, Committee on Banking Finance \& Urban Affairs, U.S. House of Representatives, at 11 (March 5, 1991) [hereinafter Totten]. The savings calculations are my own. 
vation were more than $10 \%$ of the total investment in energy supply in 1981 and 1982 . China instituted several projects to improve energy conservation. These projects included cogeneration systems, recovery of waste heat and gases, renovation of industrial boilers and furnaces, upgrading of small fertilizer plants and cement kilns, and continuous casting technology for steel processing.

China's energy conservation efforts were not limited to investment projects, however. Regulations and guidelines concerning energy use were promulgated, engineers were trained in energy conservation, and energy conservation centers were established and equipped throughout the country to provide technology consultation, equipment testing, and feasibility studies. China's investments saved an estimated 27 million standard tons of coal per year, which is equivalent to $6.3 \%$ of China's total industrial energy consumption for the year 1985 . China's average costs for improving energy efficiency were lower than the cost of new coal supply and substantially lower than unsubsidized costs of new coal supply in other countries. $^{\mathrm{b}}$

Another example is the $\$ 150$ million refurbishment by the General Electric Corporation of thirteen Tungsram incandescent bulb factories in Hungary in 1990 underwritten by the World Bank and the U.S. Overseas Private Investment Corporation (OPIC). The $\$ 150$ million could have been used to finance more than twenty new compact fluorescent lamp factories. The construction of fluorescent lamp factories could have avoided the construction of 12,000 megawatt (MW) power plants resulting in savings of $\$ 20$ billion and minimizing air pollution in a country already suffocating in smog. ${ }^{6}$

5. Mark D. Levine et al., Report to.the U.S. Working Group on Global Energy Efficiency, Energy Efficiency, Developing Nations, and Eastern Europe 37 (1991) [hereinafter Levine]; Mark D. Levine \& X. Liv, Lawrence Berkeley Laboratory, Report No. LBL-27222, Energy Conservation Programs in the People's RePUBLic OF China (1989).

6. Totten, supra note 4, at 11; Ashok Gadgil et al., Lawrence Berkeley Laboratory, Report No. LBL-30389, AdVANCEd Lighting and Window TechNologies for Reducing Electric Consumption and Peak Demand: Overseas Manufacture and Marketing Opportunities (1991) [hereinafter GadgiL]. 
The lesson from both these examples is the same: the full life cycle system costs of energy projects must be considered, not just the first cost, if energy investments are to be accurately valued. The following are a few examples of the potential of efficiency measures to save energy and capital at different levels of development.

The poor who burn wood for cooking consume three to ten times as much energy per capita as consumers in either developing or industrialized countries who have access to such modern energy carriers as liquid petroleum gas (LPG), kerosene, and natural gas. While it would be desirable to shift to these commercial fuels, the conversion costs are considerable. Translating what this means to an average citizen in Sri Lanka, the cost to convert to LPG in 1983 equaled one month's income for $70 \%$ of the population and five months' income for the poorest $20 \% .^{7}$ As a transitionary measure for those countries that cannot afford present conversion to commercial fuels for cooking, more economic and efficient stoves are available. A $\$ 1$ billion annual investment would supply efficient wood stoves to the 400 million rural households in developing countries (based on a cost of $\$ 10$ per stove with a four year life span). The fuelwood conserved could generate, in biomass-fired stoves, as much electricity as eighty large nuclear power plants costing $\$ 160$ billion. $^{8}$ On a more advanced level, it has been calculated in Brazil that investments of $\$ 10$ billion over the next 15 years in more efficient refrigerators, street lighting, lighting for commercial buildings, motors, industrial motors, and variable speed drives could preclude the construction of 22 gigawatts $(\mathrm{GW})$ of new electric generating capacity at a cost of $\$ 44$ billion. ${ }^{\ominus}$

These examples give the flavor of the energy, capital, and environmental savings achievable through conservation and full life cycle system cost consideration of energy investments.

7. OTA, supra note 1, at 53; Gerald Leach, Household Energy in South Asia, ELSEVIER APPLIED SCIENCE (1987).

8. Jose Goldemberg et al., World Resources Institute, Energy for DevelopMENT 58 (1986) [hereinafter WRI].

9. WRI, supra note 8, at 34; Howard S. Geller, Companhia Energetica de Sao Paulo, The Potential for Electricity Conservation in Brazil (1985). 
Let us now look at the insupportability of current energy supply strategies, both from an economic and environmental viewpoint, and then review estimates of the aggregate economic efficiency and energy savings potential in developing countries, the potential for renewables, and the steps recommended to achieve these potentials.

\section{Current Energy Supply Strategies}

\section{A. Insupportability of Present Energy Trends}

If present growth trends in developing country energy demand continue, world resources quite simply will be inadequate to support their needs for energy or development. ${ }^{10}$ For example, the World Bank has estimated that $\$ 125$ billion will have to be invested annually in developing countries just to provide adequate supplies of electricity (omitting needs for direct use of fuels). ${ }^{11}$ This figure is representative of the projected annual increase in the total gross national product (GNP) of all developing countries. ${ }^{12}$

The World Energy Conference projects that by pursuing current supply strategies developing countries will account for almost $60 \%$ of the global energy increase in commercial energy consumption over current levels by 2020 . Over one-third of this projected increase can be attributed to China. ${ }^{13}$ The World Energy Conference also projects (in its "moderate" economic growth case) that consumption of commercial energy in developing countries on the current supply-oriented basis will triple by $2020 .{ }^{14}$

The capital requirements of electric power growth (projected at 5 to $7.5 \%$ per year on a current trends basis) has been estimated to be $\$ 1.4$ to $\$ 4$ trillion over the next two de-

10. WRI, supra note 8, at 57; The World Bank, The Energy Transition in Developing Countries (1983). (1983).

11. The World Bank, The Energy Transition in Developing Countries

12. OTA, supra note 1 , at 13 .

13. OTA, supra note 1 , at 9 .

14. OTA, supra note 1, at 10; World Energy Conference, Global Energy PerSPECTIVES 2000-2020, 14th Congress (1989). 
cades. Unfortunately, the World Bank currently lends less than $\$ 4$ billion per year to the energy sector, while commercial lending stands at about $\$ 16$ billion per year and has been declining rapidly. ${ }^{15}$

Developing countries' foreign debt increased greatly over the last two decades to an estimated $\$ 1.3$ trillion in early $1989 .{ }^{16}$ This increase, combined with increasing interest rates, caused debt service as a share of total exports of goods and services to double from what it was in the early 1970s. "The net transfer or outflow of resources from the developing countries amounted to $\$ 38$ billion in 1987 , compared with a net inflow of $\$ 35$ billion in 1981." 17 Currently, an increasing number of developing countries are burdened with debt-servicing obligations equaling more than $50 \%$ of their export earnings. ${ }^{18}$

Supply-oriented energy strategies are difficult to foster in the face of the high capital expenditures necessary to satisfy expanding energy needs with new supply resources. Furthermore, income gained from export earnings will be diverted to meet the demands of the energy sector instead of servicing debts to the international community and satisfying the basic social needs of the countries' own population. ${ }^{19}$

Energy supply facilities (such as electricity generating stations and petroleum refineries) on which most current energy strategies of both developing countries and their finance sources rely are highly capital intensive. Twenty-five percent of both Brazil's and Costa Rica's foreign debt are from borrowing for the construction of power plants and transmission lines and Poland has invested almost $40 \%$ of its 1986 industrial investment into energy, $21 \%$ in coal alone. ${ }^{20}$ Supply acquisitions thus place major demands on scarce supplies of

15. LEVINE, supra note 5 , at $2-3$.

16. OTA, supra note 1, at 27; Human Development Report 1990, United Nations Development Programme 79 (1990).

17. OTA, supra note 1, at 27; The World BANk, World Development Report, 1989, at 18 (1989).

18. WRI, supra note 8 , at 14.

19. OTA, supra note 8 , at 20 .

20. Christopher Flavin \& Nicholas Lenssen, Worldwatch Institute, Beyond the Petroleum Age: Designing a Solar Economy, Worldwatch Paper 100, at 40-41 (1990) [hereinafter Flavin]. 
both domestic and foreign resources available for capital investments.

Commercial energy supply sector investments, such as electricity, oil, gas, and coal, represent over $30 \%$ of public investment budgets in many developing countries. Oil imports alone represent $30 \%$ or more of total export earnings of many countries. In middle income countries, energy imports and debt service account for over one-third of total export earnings, compared to almost $40 \%$ in lower-income countries (excluding China and India). ${ }^{21}$

Some developing countries emphasize domestic production of energy, but here, too, investments in highly capitalintensive energy supply systems account for a large percentage of the total investment budget, which in some countries amounts to over $40 \%$ of all public investments. Use for energy of scarce capital resources has a major impact on the amounts of investments available for other economic and social development. ${ }^{22}$ Clearly most developing countries will not be able to afford the capital necessary to continue pursuing a supply strategy, and the developed countries and multilateral banks will not be able to furnish the necessary capital.

\section{B. Population Growth Requirements}

More than $90 \%$ of world population growth can be attributed to developing countries. The current population of developing countries is approximately 4.1 billion, which is $77 \%$ of the world's population. Even if fertility rates decrease, the population of developing countries is projected to rise to 7.1 billion by 2025, and could increase to 10 billion by 2100 . Eighty-eight percent of the global population would be attributed to developing countries. ${ }^{23}$ Ninty-five percent of the projected population growth on the planet for the next century

21. OTA, supra note 1 , at 12,34 .

22. OTA, supra note 1 , at 34 .

23. OTA, supra note 1 , at 11, 26; Rodolfo A. Bulatao Et al., The World Bank Europe, Middle East and Africa (EMN) Region Population Projections (1989-90 ed. 1990). 
will occur in these countries. ${ }^{24}$ The projected population increases would result in a $75 \%$ increase in commercial energy consumption in developing countries by 2025 , even if per capita consumption remained at current levels. ${ }^{25}$

\section{Unacceptability of Environmental Costs of Current Trends}

\section{Air Pollution}

The combustion of fossil fuels has led to levels of air pollution in cities of developing countries that are among the highest in the world. The combustion of oil or gas in stationary sources, such as electric generating units and factories, is also a major contributor. In major cities of developing countries, concentrations of sulphur dioxide $\left(\mathrm{SO}_{2}\right)$ and of total suspended particulates exceed World Health Organization guidelines..$^{28}$ For example, in Mexico City the air quality was below international standards 312 days in $1989 .{ }^{27}$

The transportation sector is the largest contributor to air pollution in many cities. For example, $70 \%$ of the newborns in traffic-choked Mexico City have excessive lead levels, due to emissions of lead from gasoline. Smog levels in Santiago, Chile, largely produced by motor vehicles, regularly reach the government's declared emergency limit. In 1989, one-seventh of Bangkok's population, one million people, suffered from respiratory diseases such as emphysema, chronic bronchitis, and asthma caused by toxic gases emitted mainly from automobiles. ${ }^{28}$

In rural areas, herders burn grasslands to encourage new growth. Such brushfires in the African grasslands may burn as much as two billion tons of biomass annually, cause volitization of organic nitrogen and sulfur, and allow excessive leaching of other valuable nutrients. Brush and grassland fires may also be significant contributors to regional air pollution and

24. WRI, supra note 8 , at $\mathrm{v}$.

25. OTA, supra note 1 , at 11 .

26. OTA, supra note 1 , at 124 .

27. Levine, supra note 5 , at 31 .

28. Totten, supra note 4 , at 4 . 
may contribute modestly to the global increase in greenhouse gases. ${ }^{29}$

In both urban and rural areas, inefficient biomass fuel combustion has a significant impact on air quality. Food is typically cooked over open fires or poorly vented stoves, exposing householders, particularly women and children, to high levels of toxic smoke. ${ }^{30}$

In some countries, clean commercial fuels are either too costly or not in great supply. In China, around one-third of the coal is used in residences, almost half of which is used for cooking. The result is high $\mathrm{SO}_{2}$ concentrations in northern Chinese cities such as Beijing and Tianjin. ${ }^{31}$

The capital required to clean up this pollution and prevent future environmental deterioration competes directly with the capital needed to satisfy growing energy demands and economic development. Even if efficiency costs as much as new supply, it would be far more economic to invest in efficiency measures that would avoid these pollution effects than to invest in energy supply measures that will create additional pollution and attendant clean-up costs. The costs of pollution remediation, however, are never reflected in estimates of the costs of energy investments.

\section{Global Warming}

In 1985, developing countries contributed about onequarter (26\%) of annual global sector carbon dioxide $\left(\mathrm{CO}_{2}\right)$ emissions. ${ }^{32}$ Assuming projected energy demand growth met by current energy supply strategies, the developing country share of global $\mathrm{CO}_{2}$ emissions would increase to $44 \%$ by 2025 . By various estimates, deforestation could be the source of between roughly 7 and $35 \%$ of total annual $\mathrm{CO}_{2}$ emissions. De-

29. OTA, supra note 1 , at 118 .

30. OTA, supra note 1, at 16; Kirk R. Smith, Biofuels, Air Pollution And Health: A Global Review (1987).

31. OTA, supra note 1 , at 123.

32. Working Group III (Response Strategies Working Group), Intergovernmental Panel on Climate Change, Policymakers' Summary of the Formulation of Response Strategies: Report Prepared for IPCC 10 (June 1990); OTA, supra note 1 , at 17 . 
veloping countries also account for at least $50 \%$ of methane and nitrous oxide $\left(\mathrm{NO}_{\mathrm{x}}\right)$, two other important greenhouse gases. $^{33}$

According to data from a recent U.S. Environmental Protection Agency study, the most important contributor to projected global warming increases is fossil fuel emissions, which are estimated to more than double, from 5,200 to 10,600 teragrams per year from 1985-2025, under current supply-oriented energy growth projections. Approximately $56 \%$ of the increase would come from developing countries. Other greenhouse gases such as methane and $\mathrm{NO}_{\mathrm{x}}$ would also increase significantly. ${ }^{34}$

A number of developing countries would be especially vulnerable to rising sea levels through threats to coastal communities and ecosystems, increased vulnerability to storm damage, and inundation of low-lying arable lands. The effects on developing country agriculture could be catastrophic. In many countries too much heat and too little rain are already a major problem for producing adequate food to feed their people. The adverse effects of climate change would exacerbate the impacts of increased populations. ${ }^{36}$

While developing countries are projected to contribute more to growth of $\mathrm{CO}_{2}$, the industrial countries have contributed the lion's share of accumulated $\mathrm{CO}_{2}$ emissions. The industrial nations, as a matter of equity as well as necessity, should therefore pay the lion's share of the costs of future reductions in the developing countries.

\section{Water Effects}

Power systems are significant sources of water pollution, ranging from coal mining run-offs to thermal discharges from power plant water cooling systems to uranium mill tailings. Perhaps the largest effect on water resources, however, comes

33. OTA, supra note 1 , at 17.

34. LeVine, supra note 5 , at 31.

35. Working Group II, Intergovernmental Panel on Climate Change, Policymakers' Summary of the Potential Impacts of Climate Change: Report prom Working Group II to THE IPCC 8 (May 1990). 
from large hydroelectric dams.

Large hydroelectric dams, the energy resource of choice of many developing countries and of multilateral lending institutions, cause major environmental damage. The filling of reservoirs floods large tracts of land, uproots people, and leads to loss of agricultural lands, forests, wildlife habitats, and species diversity.

The magnitude of these projects can be mind-boggling. For example, the Akosombo Reservoir on the Volta in Ghana, with a land requirement of 8,730 square kilometers $(\mathrm{km})$, approaches the size of such small countries as Lebanon or Cyprus. The Three Gorges Dam project, under consideration for the Yangtze River in China, is the subject of controversy because it would require the resettlement of approximately one million people and deface one of China's foremost natural sites. $^{36}$

Dams also disrupt the natural flow of rivers. Changed flows can erode river beds, alter flood patterns, harm aquatic ecosystems, and interrupt the spawning and migratory patterns of fish and other species. The introduction of a new lake can affect water tables and groundwater flows and interfere with the necessary flow of nutrients, and may induce microclimatic changes in humidity, cloud cover, and rainfall. In addition, if the vegetation is not cleared from the reservoir area before flooding, rotting organic matter releases significant amounts of $\mathrm{CO}_{2}$ and methane, two potent greenhouse gases, not to mention odors.

Hydropower facilities, in turn, are vulnerable to environmental degradation. Heavier than expected siltation of reservoirs from deforested and/or degraded lands upstream can reduce the lifespan of hydroelectric projects. The Hirakud Reservoir in India, for example, was expected to be productive for about 110 years, but now has an estimated productive lifetime of 35 years. Estimated losses of $\$ 133$ million to $\$ 274$ million have been incurred by the Cachi hydroelectric station in Costa Rica from excess sedimentation caused by soil erosion. ${ }^{37}$

36. OTA, supra note 1 , at 129.

37. OTA, supra note 1 , at 129 . 


\section{Land \& Forest Impacts}

In many regions, shifting (or slash and burn) agriculture is practiced by those who migrate. It is a popular form of agriculture in West Africa, Southeast Asian hill communities, parts of South America and elsewhere. Shifting agriculture is probably the most important cause of secondary forest destruction and its impact on primary forests is comparable to the impact of commercial logging. Tremendous quantities of biomass energy are wasted through this process of forest clearing. ${ }^{38}$

In the rural areas of most developing countries, fuelwood is the major energy resource for cooking. Population increases and development needs cause serious forest depletion, resulting in major forest losses which contribute to erosion, desertification, and serious loss of biodiversity.

Commercial logging is estimated to impact 3 to 5 million hectares of primary tropical forest annually. For every tree removed, roughly five to ten other trees are destroyed. Commercial logging also develops roads that allow settlers access to forested regions, where they can clear the forests for farms and ranches. The effects on biodiversity from loss of forests is devastating.

The clearing of India's forests have resulted in flood and erosion damage estimated at $\$ 20$ billion between 1960 and 1980. Additional damages suffered include loss of topsoil, loss of property to fallows, and shortened reservoir lifetimes. Other estimates have placed direct costs upwards of $\$ 250$ million per year to repair the flood damage in India. ${ }^{39}$

The rate of global deforestation from all causes is highly uncertain, with estimated rates in the early 1980s ranging from roughly 0.5 to $1.8 \%$ annually. These rates appear to be accelerating due to increasing population and development pressures. In some countries, the situation is horrendous. For example, Ivory Coast, which has only 16 million hectares of forest remaining, suffers from deforestation at an estimated 
rate between 6.5 and $15.6 \%$ per year. ${ }^{40}$ The environmental cost of a business-as-usual scenario which seeks to accommodate population growth and development pressures with new energy supplies is environmentally insupportable, both for developing countries themselves and for world environmental sustainability.

\section{Efficiency Potential}

A number of careful studies by energy efficiency experts from around the world have concluded that energy efficiency investments can at least halve the capital needed for development and sharply reduce the environmental impacts of a supply-oriented scenario. Thus, Jose Goldemberg of Brazil, Thomas Johansson of Sweden, Amulya Reddy of India, and Robert Williams of the United States, in their study for World Resources Institute (WRI) concluded, assuming use of only commercially available or near commercial technologies, that "developing nations have an almost universally unrecognized potential to raise living standards - up to the level of Western Europe today - with only a modest $30 \%$ increase in per capita energy consumption." 41

Their conclusions are based on a sector-by-sector analysis of least cost investments in electricity, agriculture, industry, etc., and inclusion of innovations which can make economic use of domestic fuels, such as biomass, rather than imported supply technologies and fuels. They also suggest policy changes needed, both by developing countries and world lending institutions, to achieve these savings. Their study is extraordinary in its depth and the degree to which it draws on actual experienced savings in various third world countries.

As they point out, "[a]lthough it is clearly possible to achieve a standard of living in developing countries . . . to a level of amenities typical of Western Europe in the 1970s without increasing per capita energy use much, this hopeful finding should not obscure the challenge of bringing about 
this result." ${ }^{\prime 2}$ While the capital requirements are less, they are still far greater than what is presently being devoted to energy for development, and there are substantial institutional changes required to achieve these savings both in the developed world lending institutions and in the developing countries themselves.

Another fine and thorough report by some of the foremost energy efficient experts in the United States, the U.S. Working Group on Global Energy Efficiency, issued in April, 1991, came to similar conclusions of dramatic capital savings achievable with only modest energy efficiency improvements (compared to the technical efficiency improvements possible with the most efficient technologies available today). The Group also calculated the environmental savings potential from its efficiency measures. ${ }^{43}$

Comparing a reference scenario based on current supplyoriented energy strategies to an efficiency scenario based on introduction of technologies and industrial processes actually being used in industrialized countries today, and giving examples of the successful introduction of such measures in a number of developing nations, the Group found impressive potential economic and environmental savings in the efficiency scenario. The Group projects a $50 \%$ reduction in capital requirements for the energy sector, amounting to savings of $\$ 50$ billion 1990 dollars from $1985-2000$ and $\$ 1.89$ trillion dollars from 2001-2025. The Group finds percentage reductions in primary energy consumption in 2025 of $45 \%$ in Eastern Europe, $33 \%$ in South and East Asia, $30 \%$ in China, $26 \%$ in Africa, and $22 \%$ in Latin America. ${ }^{44}$ Under the efficiency scenario, $\mathrm{CO}_{2}$ emissions from fossil fuels drop $28 \%$ and global emissions are reduced by $25 \%$ in 2025 , nearly two-thirds from efficiency reductions in developing countries. These results would reduce eventual global warming by one degree Fahrenheit or more and total $\mathrm{NO}_{\mathrm{x}}$ emissions in 2025 by $18 \% .{ }^{45}$

42. WRI, supra note 8 , at 55 .

43. LEvine, supra note 5 , at 37 .

44. LeVine, supra note 5 , at 26.

45. Levine, supra note 5 , at 32 . 
One last study by Howard Geller, Executive Director of the American Council for an Energy-Efficient Economy, concludes that slowing the rate of growth in electricity demand by just $1 \%$ per year would save developing countries at least $\$ 130$ billion in investment costs for electricity supply facilities, with net savings of about $\$ 100$ billion. $^{46}$

Let me give just a few examples of specific efficiency technology savings potentials in developing countries from these papers. A study conducted in India concluded that a $\$ 7$ million factory could produce enough fluorescent lightbulbs (12.3 million bulbs in seven years) to save the country 1,587 MW of coal-burning electric capacity, amounting to $\$ 2.4$ billion in savings, with savings of $\$ 950$ million in foreign exchange. The study concluded that a compact fluorescent lightbulb factory would be 320 times cheaper than constructing new coal-burning power plants needed to power incandescent bulbs. Promoting domestic production of efficient technologies, rather than importing the products, has particular leverage for developing countries, enabling them to reduce their foreign debt and pollution while still meeting development goals. ${ }^{47}$

In Brazil, the cost of an energy efficient motor is recovered within three years as long as the motor is used at least 2000 hours per year and electricity costs at least three cents/ kilowatt-hour (kWh). Power demand is reduced at a cost of under $\$ 250 / \mathrm{kW}$, versus central station power construction costs of about $\$ 3000 / \mathrm{kW} \cdot{ }^{48}$ In India, it has been estimated that a comprehensive national program for replacing inefficient water pumps with more efficient models would cost $\$ 650$ million over about five years, but could lead to a reduction in pump operating costs of $\$ 400$ million per year. ${ }^{48}$

A study of residential and small office buildings in Pakistan estimated that electricity consumption can be decreased

46. Howard S. Geller, American Council for an Energy-Efficient Economy, Improving End-Use Electrical Efficiency: Options for Developing Countries 30 (1986) [hereinafter GELLER].

47. Nicholas Lenssen, Worldwatch Institute, Ray of Hope for the Third WoRLD 37, 38 (Sept./Oct. 1990).

48. Geller, supra note 46 , at 9.

49. Geller, supra note 46 , at 23. 
$15 \%$ by reducing infiltration, $20 \%$ by improving air conditioner efficiency, $15 \%$ by adding minimal insulation to roofs, and $12 \%$ by placing reflective coating on roofs. Combining these measures could achieve savings of $29 \%$ in Karachi (where buildings are only air conditioned) and $40 \%$ in $\mathrm{Pe}-$ shawar (where buildings are heated and air conditioned)..$^{\text {so }}$

A number of countries have not only studied the potential savings from efficiency measures, but have made substantial starts towards implementing them. China's impressive beginnings have been described earlier. ${ }^{51} \mathrm{~A}$ few other examples follow:

Brazil established a national electricity conservation program (PROCEL) in 1985, funding conservation projects carried out by state and local utilities, universities, and research institutes. By early 1990, PROCEL funded over 150 projects totaling approximately $\$ 20$ million. Except for about $\$ 1$ million from the World Bank as seed money, funding has come from the national electric utility, Eletrobras. One of PROCEL's larger projects was the replacement of over 280,000 street lamps with mercury vapor and high pressure sodium lamps, resulting in savings of about $115 \mathrm{GWh} / \mathrm{yr}$. PROCEL also has programs for information, appliance labeling, energy audits, low interest loans through the National Development Bank, and cooperative programs with industries, utilities, and state and local governments.

PROCEL estimates that its efficiency programs have resulted in direct savings of $1,070 \mathrm{GWh} / \mathrm{yr}$ as of 1989 , and considering its activities with other organizations, an estimated $2,500 \mathrm{GWh} / \mathrm{yr}$. This is equivalent to central station power plants having 280-650 MW capacity deferring investment of $\$ .06-\$ 1.3$ billion in new power plants, transmission, and distribution facilities. $^{.2}$

In one other example, in 1985, the government of Tunisia

50. LEvine, supra note 5 , at 21.

51. See supra note 5 , at 4.

52. Howard S. Geller \& Jose R. Moreira, American Council for an EnergyEfficient Economy, Brazil's National Electricity Conservation Program (PROCEL): PRogress AND Lessons (1990). 
created the Agence de Maitrise del'Energie (AME), an independent conservation agency which conducted energy audits mandated by the government for the 200 largest industrial, transport, and commercial companies, representing $80 \%$ of Tunisia's total commercial energy consumption. The agency offers a variety of tax, import, and loan incentives, financed in part through a half cent per litre sales tax on fuel oil and gasoline. AME is working with the National Institute for Standards to establish appliance efficiency standards and is seeking to promote manufacture of energy efficient products.

The marginal energy intensity of Tunisia fell from 1.3 in 1985 to 0.8 in 1989 , attributable in part to these efforts. Energy consumption in the highly energy-intensive cement industry decreased by $40 \%$ during this period, in large part because of AME's auditing, training, and implementation work with the industry. ${ }^{53}$ From both economic and environmental viewpoints, it has been demonstrated that energy efficiency investments represent enormous untapped opportunities to save immense amounts of energy and capital, and prevent environmental damage.

\section{E. Renewables Potential}

The vast majority of developing countries are in the sunbelt, many near the equator where the heat and light of the sun are available year-round. The potential for meeting their energy needs with solar energy and thus permanently relieving them from the burdens of fuel imports is enormous. A recent U.S. government scientific laboratories study indicated the potential of renewables in the United States (which has much less of its territory in the sunbelt than most developing countries) could supply up to $50 \%$ to $70 \%$ of current U.S. energy use by the year $2030 . .^{54}$

53. Levine, supra note 5 , at $40-41$.

54. Flavin, supra note 20, at 17; Idaho National Engineering Laboratory (INEL) et al., Ofpice of Policy, Planning and Analysis, U.S. Department of Energy, The Potential of Renewable Energy: An Interlaboratory White Paper (1990) [herinafter INEL]. The three U.S. scenarios in this report envision renewable energy supplies growing by approximately $300 \%, 450 \%$ and $600 \%$ levels by 2030 . 
Contrary to popular belief, renewable energy sources, primarily biomass and hydropower, currently produce approximately $20 \%$ of the world's energy, with biomass providing $35 \%$ of developing countries' total energy needs. However, biomass is often produced in a manner that is not renewable in the long run and large hydroelectric dams cause major environmental problems. . $^{\mathrm{ss}}$

The focus in the future for employment of renewable energy must be on direct harnessing of the sun, through photovoltaic, solar thermal, wind, and sound biomass applications, and more widespread use of geothermal energy.

\section{Solar Photovoltaics}

Photovoltaics, direct conversion of the light of the sun into electricity, is increasingly being used in developing countries for remote village lighting and medical refrigeration applications, fueling rural irrigation pumps, and the like. Over 6,000 villages in India rely on photovoltaics. Indonesia and Sri Lanka also have begun working on ambitious photovoltaic programs. ${ }^{56}$ Typical examples include the Bohoc School in Haiti which replaced a diesel generator costing $\$ 6,000$ per month for fuel and maintenance with a photovoltaic system which cost the price of just one year's diesel fuel. The system supplies twenty buildings with power for lighting, refrigeration, ceiling fans, and appliances. In 1989, photovoltaic-powered water pumping systems, installed in eleven villages in Tata Province, Morocco, served over 20,000 people. The pumps can supply up to 40,000 gallons of water per day more economically (and feasibly) than would diesel-powered pumps. $^{.77}$

At the Electric Power Research Institute (EPRI) in Cali-

55. Flavin, supra note 20 , at 18 .

56. Flavin, supra note 20, at 20; U.S. Department of EnErgy, Energy Technologies and the Environment (1990): U.S. Department of Energy, Photovoltaic Energy Program Summary (1990); Ken Zweibel, Harnessing Solar Power: The Photovoltaics Challenge (1990) [hereinafter Zweibel].

57. U.S. Agency for International Development (AID), Improving the Quality of Life With Renewable Energy (1990) [hereinafter AID]. 
fornia, researchers discovered that by deploying solar cells over an area of 59,000 square kilometers, less than one-third of the area now used by the United States' military, all current United States' electricity needs could be met. ${ }^{58}$ Solar cell electricity should cost ten cents a kilowatt-hour by the end of the decade, and by 2030 much of the world's electricity could be provided by photovoltaics for as little as four cents a kilowatt-hour. ${ }^{.8}$

The most exciting future application of photovoltaics, however, is hydrogen produced from solar cells. Hydrogen is the cleanest burning fuel. It produces only water vapor and small amounts of nitrogen oxides. However, these by-products can be eliminated in a fuel cell by chemically combining hydrogen with oxygen. Hydrogen powered electric cars can be powered by hydrogen fuel cells which are $70 \%$ efficient. $\mathrm{Hy}$ drogen can also be stored or used directly in cars by conversion into metal hydrides which release hydrogen when heated. And hydrogen can be transported in pipelines, just like natural gas. German and Saudi engineers are currently working on an electrolysis system generated by photovoltaic cells. ${ }^{30}$

\section{Solar Thermal}

Solar thermal technologies, using the heat of the sun, also have great potential both for local and electric power station applications. Approximately two million villages not serviced by electricity are located within twenty degrees latitude of the equator. These villages are prime locations for solar thermal power. ${ }^{\text {B1 }}$

Solar thermal energy is an excellent source for supplying hot water for cooking and heating, which in industrial coun-

58. Flavin, supra note 20, at 47; John Shaefer \& Edgar DeMeo, Electric Power Research Institute, An Update on U.S. Experiences with Solar Power Generation, Proceedings of the American Power Conference (Apr. 23, 1990).

59. Flavin, supra note 20, at 21; ZWEIBEL, supra note 54; INEL, supra note 54.

60. Flavin, supra note 20, at 24, 25; Joan M. Ogden \& Robert H. Williams, World Resources Institute, Solar Hydrogen (1989); German Aerospace Research Estabiishment \& King Abduaziz City por Science and Technology, Hysolar: SoLAR HYDROGEN ENERGY (1989).

61. AID, supra note 57, at 10-11. 
tries accounts for 30 to $50 \%$ of energy use and even more in the developing world. The potential exists for economic use of solar thermal energy to replace existing sources in most of the world for all low temperature hot water applications and in new buildings for heating and cooling to reduce energy consumption by more than $80 \% .^{62}$

In certain nations, such as Cyprus, Israel, and Jordan, solar panels provide hot water in 25 to $65 \%$ of the homes. In the United States, there are over one million active solar heating systems and 250,000 passive solar homes, which rely on natural flows of warm and cool air. The steam needs of many industries can also be serviced by advanced solar collectors. ${ }^{63}$

\section{Geothermal}

Geothermal resources, which are localized, can be found in many regions. Currently, more than 5,600 MW of geothermal power are supplied throughout the world. Geothermal sources account for $40 \%$ of El Salvador's supply of electricity, $28 \%$ of Nicaragua's, and $11 \%$ of Kenya's. ${ }^{64}$ In the Philippines, geothermal electric generation amounts to over $900 \mathrm{MW}$ of installed capacity, totalling $20 \%$ of the electricity generated. Mexico has more than $650 \mathrm{MW}$ of installed geothermal electric generation, and in Reykjavik, Iceland geothermal supplies up to $95 \%$ of the city's heat. ${ }^{65}$ Substantial geothermal resources exist in most Pacific Rim countries, along East Africa's Great Rift Valley, and around the Mediterranean Sea.

\section{Wind}

Wind energy also has great potential and is currently eco-

62. Flavin, supra note 20, at 18; U.S. EnERgy Information Agency, Dept. of Energy, Annual Energy Review 1989, (1989); Solar Techinical Information Program, U.S. Solar Energy Institute Energy for Today: Renewable Energy (1990). See also John H. Nielson, Denmark's Energy Future, EnErgy Policy (Jan./Feb. 1990).

63. AID, supra note 57 , at $18-19$.

64. AID, supra note 57, at 23; P.M. Wright, Developments in Geothermal Resources, 1983-1988, U.N. Energy Statistics Yearbook, U.N. Doc. No. S1/ESA/ STAT/SER.J/32 (1988), reprinted in The American Association of Petroleum GeOLOGIST BULLETIN (Oct. 1989).

65 . AID, supra note 57 , at 8. 
nomically competitive for electric applications. At Pacific Northwest Laboratories in the United States, researchers have estimated that wind farms installed on the windiest $1.5 \%$ of the continental United States can supply $25 \%$ of current United States generating capacity. In the United States, most prime windfarm sites are barren grazing lands in the western states which would hardly be affected by such development. ${ }^{B 6}$

Wind conversion has recently been introduced in developing countries. One example is the Naima Commune Water Pumping Project in Morocco. Here, two $10 \mathrm{~kW}$ wind electric water pumping systems were adapted to the existing water supply network serving 6,000 people and their livestock. These systems replaced diesel generators which could only be operated a few hours a day due to the enormous costs. Over 25,000 wind turbines supply electricity in the Inner Mongolia region of China to power lighting and appliances. China currently produces up to 10,000 wind turbines per year. ${ }^{67}$

\section{Biomass}

Among the energy sources that can be used to support development, biomass is particularly significant. Biomass can be produced on energy farms and, in many instances, the costs to produce bioenergy can be much lower than the world oil price. Bioenergy production is attractive where unemployment or underemployment are chronic, since large amounts of labor are involved in growing and converting the biomass. Bioenergy production can provide decentralized energy sources, helping to spur rural development in developing countries and minimize migration to urban areas. ${ }^{68}$

The most successful program for producing bioenergy is Brazil's program to make ethanol from sugar cane. This program produced eleven billion liters of ethanol from sugar cane

66. Flavin, supra note 20, at 47; D.L. Elliott et al., U.S. Aerial Wind Resource Estimates Considering Environmental and Land-Use Exclusions, presented at the American Wind Energy Association Windpower ' 90 Conference in Washington D.C. (1990).

67. AID, supra note 57 , at 7 .

68. WRI, supra note 8 , at 39 . 
in 1985, replacing about $55 \%$ of the gasoline that would have been required in the absence of the program. Almost two million Brazilian automobiles are fueled solely by pure alcohol, with the remainer of the automotive fleet operating on gasohol (a gasoline-ethanol blend with $20 \%$ ethanol). ${ }^{80}$

The cost of producing ethanol in Brazil was estimated at $\$ 1.19$ to $\$ 1.33$ per gallon (1983 U.S. dollars) of gasoline displaced, competitive at 1981 gasoline prices but not at the low level to which prices fell in the late 1980s. Brazil therefore had to subsidize the program for several years, but now has developed the most advanced ethanol producing processes in the world, so that the ethanol is again competitive. ${ }^{70}$

The Brazilian ethanol program has been very effective in creating employment. While Brazilian industry requires an average investment of $\$ 42,000$ per job, and the oil refining petro chemical complex at Camacari, Brazil requires an investment of $\$ 200,000$ per job, the ethanol program requires an investment of only $\$ 6,000$ to $\$ 28,000$. Approximately 475,000 full-time jobs in agriculture and industry have been directly created by the alcohol program, while another 100,000 jobs have been indirectly created in areas such as commerce, services, and government. ${ }^{71}$ An additional advantage of the program is that alcohol production is carried out primarily with local currency, but gasoline is paid for in hard currency.

Producer gas is a further product of biomass resources. By partially oxidizing the biomass feedstock in air, a gas can be produced in low-cost converters with 60 to $70 \%$ overall energy efficiency. Producer gas can be used to power small generators for agricultural pumping, village electrification, and rural industrial applications, or it can be piped to individual homes for cooking. Today, it is usually made from charcoal rather than wood because the gas from charcoal is tar-free and will not clog engines. However, since wood is so much less costly, gasifier research and development is targeting the pro-

69. WRI, supra note 8 , at 40 .

70. WRI, supra note 8, at 43; Howard S. Geller, Ethanol Fuel from Sugar Cane in Brazil, 10 ANn. Rev. OF ENERgy 135 (1985).

71. WRI, supra note 8 , at 43 . 
duction of tar-free gas from wood and other raw biomass sources. $^{72}$

Power production from biomass fuels is best done in small cogenerators to take advantage of use of the fuel both for heat and electric generation. Several small biomass-based cogeneration facilities have been built recently. The cogeneration facilities use steam turbines, smaller than the turbines used in large, central station power plants, to produce electricity. However, gas turbine technology is more promising since it can be more thermodynamically efficient in cogeneration and tends to be cheaper than the steam turbine at smaller scales. ${ }^{73}$ Cogeneration using gas turbines at sugar mills fired with gasified bagasse (the residue remaining after sugar juice is extracted from sugar cane) has proven economically efficient and indicates the potential for some $40 \mathrm{GW}$ of bagassebased electrical generating capacity at sugar mills throughout the world ${ }^{74}$

Biomass, as a major energy resource in support of development, requires production on a renewable, sustainable basis on energy farms. The average cost of producing biomass on World Bank-sponsored farms has been about $\$ 1$ per gigajoule (GJ) compared to more than $\$ 4$ per GJ for oil at $\$ 25$ per barrel - and again, the biomass does not have to be imported..$^{75}$

\section{Recommendations}

A. Basic Needs Strategy Accenting Labor-Intensive Technologies and Use of Indigenous Materials and Manufacture

To achieve the remarkable capital savings and economic benefits which are possible through investment in energy-sav-

72. WRI, supra note 8 , at $40-42$.

73. WRI, supra note 8, at 43-44; Robert H. Williams, Industrial Cogeneration, 3 ANN. Rev. OF ENERgY 313 (1978).

74. WRI, supra note 8, at 44; ERIC D. Larson et. al., Princeton University Center for Energy and Environmental Studies, Steam-Injected Gas Turbine Cogeneration for the Cane Sugar Industry: Optimization Through Improvements in Sugar Processing Efficiencies (1987).

75. WRI, supra note 8 , at 65,66 . 
ings and renewable technologies, all the actors involved in energy planning and investment for developing countries must make substantial institutional and attitudinal changes. The focus must be on meeting basic human needs in developing countries, with minimal cost to society. By raising the standards of living in rural areas, where the vast majority of developing country residents now reside, emphasizing basic needs would reduce the pressure to leave the countryside and thereby reduce the need to expand costly city services.

The accent should be on local manufacture and use of local materials where possible, minimizing the need for imports and energy-intensive processes. In general, developing countries should produce more of what they consume and consume more of what they produce, trading more with other developing countries and less with industrialized countries. A development strategy emphasizing the production of basic materials mainly for domestic markets would require far less energy than one emphasizing the production of basic materials for export.

Satisfying basic human needs requires seeking labor-intensive methods of production to generate more jobs for the poor. Many sophisticated energy production technologies being promoted by industrialized countries and financed by world lending institutions are ill-suited to industrializing countries. These technologies have been designed to replace workers with machines wherever possible. Yet, most developing countries are capital poor and labor rich. The current world population will be outnumbered by the working population of the less developed nations by 2025. Most less developed countries are in need of modern labor intensive investments. $^{76}$

Industries have different employment needs. Raw material processing industries are generally highly energy intensive while fabrication and finishing industries are highly labor intensive. Since manufactured exports yield more foreign currency than raw materials, much more value would be gained

76. WRI, supra note 8 , at $\mathrm{v}$. 
and employment created in developing countries if finished materials were exported instead of processed basic materials. ${ }^{77}$

In determining developing country strategies, these countries, such as donor countries and lending institutions, must make meeting local needs, accommodating local conditions, and minimizing life cycle system costs in the developing countries top priority, rather than importing what the industrial countries would like to sell. The latter will be of very short term advantage to industrialized countries if what they export is ruinous to developing countries economically and environmentally.

\section{B. Recognizing Developing Country Differences}

In devising appropriate energy strategies for developing countries, the large differences between them must be considered and respected. Developing countries differ widely in their incomes, energy resources, urbanization, population growth, development strategies, imports, exports, debts, tax structures - indeed in every crucial aspect affecting their energy-related conditions.

The "energy crisis" was a result of reliance on oil and the other modern energy forms that shape the lifestyles of the affluent few. Yet, the majority of the world's population, living in villages and small towns in Asia, Africa, and Latin America, are rarely exposed to modern energy forms. Fuelwood is their chief energy source, and the United Nation's Food and Agriculture Organization (FAO) estimates that 100 million human beings now suffer an acute scarcity of fuelwood while one billion suffer from a fuelwood deficit. ${ }^{78}$

In the upper middle-income developing countries such as Brazil, Argentina, Algeria, Venezuela, and Korea, the per capita incomes are more than six times higher than in the low-

77. WRI, supra note 8 , at $25,27$.

78. WRI, supra note 8, at 11; Food and Agriculture Organization, Forestry Department, A Global Reconnaissance Survey of the Fuelwood Supply Requirement Situation, Report of the Technical Panel on Fuelwood and Charcoal on its Second Session of the Preparatory Committee for the United Nations Conference ON New and Renewable ENergy (1981). 
income countries. There are also vast differences between the oil producing countries and the those that must import the majority of their oil and other energy supplies. Traditional fuels supply up to $90 \%$ of total energy use in the low-income African countries as opposed to under $20 \%$ in the middle-income develping countries. ${ }^{79}$ Less than $3 \%$ of the world's total commercial energy consumption is consumed by the fifty African countries. While global energy concerns are focused on the large consumers, the energy needs of the low-income developing nations remain a matter of life and death to their people and are critical to their development prospects. ${ }^{80}$

These wide differences between developing countries must be taken into account by industrial countries and multilateral banks in devising energy strategies suitable for their needs. While there are many elements in common, particularly as they relate to the advantages of use of efficiency technologies and renewable energy over use of capital-intensive and highly polluting supply resources which require imported fuels, the impacts and feasibility of strategies is highly dependent on the situation of the individual country. A sound energy strategy requires tailoring energy programs to each country (or in some cases by region). ${ }^{81}$

I will now venture to make specific detailed recommendations of changes that would be helpful in developing countries, lending countries, and institutions to accomplish an affordable least-cost energy strategy.

\section{Developing Countries}

\section{Information Needs}

Change within any country must emanate from a desire and will of that country to adopt the requisite modifications. In the case of energy efficiency measures, of course, this implies a knowledge of the energy efficiency technologies and their potential economic and environmental advantages over

79. OTA, supra note 1 , at $5,29$.

80. OTA, supra note 1 , at 8.

81. WRI, supra note 8 , at 57 . 
supply alternatives. This is an awesome challenge in and of itself because of the infancy of efficiency technology introduction in the industrialized countries, the lack of adequate data, the inadequate means to communicate the available information and the paucity of knowledgeable experts in the world.

Conferences such as this, sponsored by the United Nations, are enormously helpful in getting the required information to the developing government officials who need the information in order to make informed decisions. Developing country officials responsible for energy-related decisions should seek to inform themselves of the options available and their comparative costs and benefits. The regional efficiency and renewable centers recommended by many of the best experts in the field, and here endorsed, could be very helpful.

As indicated below in recommendations for developed countries and MDBs, donors and lenders should make exponentially greater efforts to assist with dissemination of efficiency and renewable information and provide for relevant training and financing of efficiency investments. Effective efforts are starting to be devoted to this information function now with respect both to identification of efficiency products and policies for instituting least cost planning and efficiency regimens. Eric Larson at Lund University in Sweden has recently published a "Technology Menu for the Efficient End Use of Energy," Tunisia has developed a list of European efficiency technology vendors, and the International Institute for Energy Conservation is preparing policy databases on leastcost utility planning, energy efficiency in buildings and appliances, and energy efficiency in motor vehicles. ${ }^{\mathbf{2 2}}$

From a different information perspective, public education about energy efficiency opportunities is also important, though experience in the United States indicates clearly that information programs alone are not sufficient to overcome the market barriers to customer acquisition and installation of ef-

82. Eric D. Larson, et al., The Technology Menu for Efficient End Use of Energy: Volume 1: Movement of Material; Lund University (SWeden), EnvironMEnTAl ANd Energy Systems Studies (1989); conversation with Michael Totten, International Institute for Energy Conservation, Washington, D.C. (Apr. 20, 1991). 
ficiency technologies. Information programs work best when accompanied by technical assistance, correct pricing signals, financing, and efficiency regulations. South Korea has a comprehensive program that has resulted in substantial energy savings. Appliance efficiency labelling can be an effective informational device. Brazil has a labelling program for refrigerators, the Philippines has one for air conditioners, and South Korea has a comprehensive labelling program. ${ }^{83}$

\section{Least Cost Planning}

Developing countries should adopt periodic least cost energy plans, drawing a blue print of how best to supply the energy services they need to meet their development goals at least societal cost. Demand-saving investments should be weighed on the same scale as additions to energy supply, taking into account the full life cycle system costs and including environmental costs.

It is important to include environmental costs, because they involve real costs people have to pay for increased health care, lost agricultural crops, etc., which are not included in energy prices. These unincluded costs (known as externalities) can be very large.

Pace University Center for Environmental Legal Studies has done a study of the environmental externality costs to society of pollution from electricity which calculates from a review of world-wide studies, that the uncontrolled costs to society from average existing U.S. coal-burning power plants, using soft coal, is about the same as the cost of running the power plant itself. ${ }^{\mathbf{8 4}}$

It also is important to include in energy plans the energy component of all other aspects of development activities not just the power sector alone. As noted before, the industrial mix, natural resource management, land-use planning, the efficiency of home appliances such as refrigerators pur-

83. GeLler, supra note 46 , at 55-57.

84. Richard L. Ottinger, et. al., Environmental Costs of Electricity (1990). The book is distributed in soft cover by the American Council for an Energy-Efficient Economy in Washington, DC. 
chased, the construction practices of buildings, etc., all have critical energy and environmental cost consequences which need to be considered. A least cost energy plan confined to coal, oil, natural gas, and electricity resources would be useless. The end-uses of those energy resources is where energy will be saved and environmental damage avoided.

\section{Policy Direction}

If it is determined from least cost planning that renewable and energy efficiency technologies and practices are the most advantageous and least cost options for the country, then a directive to this effect from the top government officials in the country, executive and legislative, is invaluable. The government must establish and fund (itself and through applications to lenders) the local institutions necessary to educate and train local personnel about renewable and efficiency technologies and practices, install the relevant technologies, provide the requisite financial tools to enable acquisition of the technologies, provide a system of incentives and disincentives to motivate people to take advantage of the energy plan, etc.

One device that has proved effective in some developing countries is for the government to set efficiency targets. For example, in the Philippines the government established a comprehensive reporting, targeting, and managing program for larger industrial and commercial firms. These firms must set efficiency targets and report quarterly consumption. As of 1983, more than half of the 401 firms were complying with the reporting procedures. ${ }^{85}$

\section{Tariffs, Subsidies, Price Controls and Taxes}

Removal of existing energy tariffs, subsidies, price controls and tax regimens that favor energy-intensive technologies and discourage introduction of efficient equipment and practices is a difficult but necessary requisite to achieving a least-cost energy strategy.

85. Geller, supra note 46 , at 45. 


\section{i. Tariffs}

Removal of tariffs and import restrictions which penalize importation of energy efficient and renewable technologies and factories to produce these technologies locally is an obvious requisite to promoting these technologies. The Philippines, for example, has removed import duties from a variety of efficient technologies. ${ }^{86}$

An unfortunate example of the effect of import restrictions can be found in Brazil. There, import restrictions prohibit a Brazilian manufacturer, who assembles energy-efficient air conditioners for export to the United States using energyefficient compressors imported from Japan, from using these compressors on air conditioners sold domestically. Thus, the domestic market, which consumes some 200,000 units per year, is restricted to inefficient, noisy compressors that are domestically produced. Since each domestic unit uses $.5 \mathrm{~kW}$ of peak power, an extra $100,000 \mathrm{~kW}$ of electrical capacity is needed to supply these new units, requiring an additional annual investment of $\$ 100$ million by the utility. However, the manufacturer would be able to produce compressors that are twice as efficient with an investment of $\$ 30$ million. The results would cut annual utility investment requirements by half. $^{87}$

\section{ii. Subsidies}

Removal of subsidies to highly polluting and inefficient energy fuels and equipment is equally obvious, but can be more difficult politically to implement. Since energy subsidies are usually adopted with the ostensible purpose of helping the poor obtain access to them, subsidy removal should be accompanied by direct assistance to the poor to meet energy needs.

Energy subsidies in most developing countries in fact help the wealthy who consume most commercial fuel and electricity, far more than the poor who often use no commercial energy resources. At any rate, subsidies are a very inefficient

86. GELlER, supra note 46 , at 62 .

87. WRI, supra note 8 , at 63 . 
and costly way of helping the poor. They result in serious misallocation of resources and inadequate revenues to finance resource operations and expansion. Subsidies tend to increase unemployment as energy is substituted for labor, and encourage over-investment in energy-intensive industries at the expense of other sectors. They also result in foregone revenues and inefficient use of energy. It would be far better to price fuels at market rates and assist the poor directly in meeting the higher costs.

A few examples of the deleterious effects of energy subsidies include the following. In China, consumer subsidies for heavy fuel oil and crude oil amounted to the equivalent of $\$ 5.4$ billion; electricity subsidies, $\$ 8.9$ billion; and coal subsidies $\$ 19.4$ billion in 1987 , amounting to $7 \%$ of China's GNP and $20 \%$ of its export earnings. ${ }^{88}$

Petroleum subsidies in Peru totalled $\$ 301$ million. These foregone revenues amount to almost three-quarters of Peru's total export revenues and about $2 \%$ of its GNP. These subsidies significantly added to Peru's growing debt burden since large foreign exchange earnings were sacrificed. Peru has since attempted to slowly remove its price subsidies. ${ }^{89}$

In Egypt, petroleum subsidies by the government amounted to $\$ 4$ billion in 1985 , twice the value of petroleum exports. This figure is equal to 13\% of Egypt's GNP and $88 \%$ of its export revenues. ${ }^{90}$

Domestic oil consumption in countries such as Mexico, China, and Peru, is large in relation to their oil imports. These countries could gain large foreign exchange benefits from domestic conservation. A $5 \%$ reduction in domestic oil consumption by China would increase its exportable surplus by $25 \%$ and lead to a $6 \%$ increase in China's total export revenues. A $5 \%$ reduction would increase exportable supplies by roughly $20 \%$ in Peru, $7 \%$ in Egypt, and $4 \%$ in Mexico. ${ }^{91}$

88. Mark Kosmo, World Resources Institute, Money to Burn? The High Costs of ENERgY Subsidies 34 (1987) [hereinafter Kosmo].

89. Id.

90. Id. at 35 .

91. Id. at 36 . 
Temporary tax incentives can be useful for the introduction of new technologies, such as solar and efficiency equipment, but the danger is that the incentives will become permanent, and subsidies for "good" resources are as market distorting as any others over the long term.

\section{iii. Price Controls}

Price controls are a particularly pernicious form of subsidy, again adopted ostensibly to help the poor, but in fact they benefit the wealthy. Energy price controls are in widespread use in developing countries, frequently representing a major drain on revenues and disabling the introduction of efficiency investments.

One study revealed that in thirty out of thirty-seven developing countries, the revenues generated by the electricity tariffs could not cover the total operating costs, including allowances for new equipment or system expansion. ${ }^{92} \mathrm{~A}$ twenty year survey financed by the World Bank of electric power projects reveals a consistent decline in key financial indicators as electricity revenues lagged behind rising costs. ${ }^{93}$

Natural gas is the most underutilized fossil fuel, largely because low producer prices discourage its production in many countries. The high share of flared gas in developing countries, due in part to low domestic natural gas prices, is $47 \%$ of total production in comparison to $4 \%$ in nations in the Organization for Economic Cooperation and Development (OECD) ${ }^{94}$ China's experience demonstrates the effect of low natural gas prices on production. From 1978-1983, the average cost of natural gas production in China increased by $59 \%$ while prices increased by only $25 \%$. The average rate of return on gas production fell from 14 to $-22 \%$, resulting in a decrease in gas production of $16 \%$. Prices ranged from 8 to

92. OTA, supra note 1, at 37; Lawrence J. Hill, Energy Price Reform in DevELOPING Countries: ISSUES AND OPTIONS (1987).

93. OTA, supra note 1, at 37; World Bank, Review of Lending for Electric Power, Industry and Energy Department Working Paper (Energy Series paper No. 2) (March 1988).

94. OTA, supra note 1 , at 37 . 
$15 \%$ under average costs. ${ }^{95}$

Energy prices clearly correlate with efficiency. One study shows that $50 \%$ of the differences in energy intensity among OECD nations is attributable to prices. The study shows that the main reason why Eastern European countries use 30 to $40 \%$ more energy per unit of GNP than do countries in the West is that between 1973 and 1981, real energy prices in the OECD countries increased by $82.4 \%$, while real energy prices remained virtually constant in Eastern Europe. ${ }^{96}$

\section{iv. Pollution Taxes}

Taxes on energy or pollution which internalize the costs to society of inefficient and polluting resources and equipment can be very helpful in achieving program goals. These are economically justified because they represent very real costs to society which, under current practice, are not included in the price of energy delivered. Pollution taxes are just starting to be considered by industrialized nations and the international community for this reason. Pollution taxes can raise significant revenue, while at the same time discourage polluting production practices.

\section{Establishing Regional Centers}

Regional centers to promote renewables and efficiency measures, conduct training, and purchase renewable and efficiency products, can provide considerable economies, particularly among the poorer and smaller countries. Bundling the purchase of equipment for several countries also could make larger acquisitions more amenable to multilateral bank lending. In some areas, regional agencies already organized for other purposes, such as the Organization of American States or ASEAN, could be used as vehicles for establishing such centers.

There is a clear need for research and development to create efficiency measures best adapted to the materials and

95. Kosmo, supra note 88 , at 45 .

96. Kosmo, supra note 88 , at 29 . 
needs of developing countries in different regions. Local manufacture of technologies will also require research to determine the best use and adaptability of local materials and skills. Regional technology centers patterned on the U.S. Electric Power Research Institute (EPRI), which does electric systems research for U.S. utility companies, would be very helpful for this purpose. The EPRI approach lends itself to the design of environmentally superior products which are modular and capable of achieving the economies of mass production. ${ }^{97}$

A good developing country model for the kind of research center advocated is the Indian Program to Accelerate Commercial Energy Research (PACER) established in 1987 and funded by the U.S. Agency for International Development and the government of India. PACER's objective is the accelerated development of innovative energy and electric power technologies and their adoption in the Indian marketplace. It involves cooperation among scientific institutions, industrial and commercial enterprises, and end-users. ${ }^{98}$

\section{Building Codes \& Appliance Efficiency Standards}

Industrialized countries have found that one of the most rapid and cost-effective ways of improving end-use efficiency is adoption of building codes requiring minimum efficiency practices, and efficiency standards for appliances sold within their jurisdictions. While political and cost considerations usually prevent these standards from being set at optimal efficiency levels, substantial improvements can be achieved without a lot of effort or bureaucracy.

Building codes are being adopted in some developing countries, particularly in the ASEAN countries. In Malaysia, for example, the Ministry of Energy, Telecommunications, and Posts has initiated development of energy standards for new buildings, aimed at reducing overall usage by $10 \%$ by

97. David Jhirad, Power Sector Innovation in Developing Countries: Implementing Multifaceted Solutions, 15 ANN. REv. of ENERGY 365, 372 (1990) [hereinafter Jhirad].

98. Id. at 375 . 
1991 (5-15\% for lighting, $5-10 \%$ for air-conditioning, and $15-$ $20 \%$ relating to heat gain through building envelopes). ${ }^{99}$

The Philippines mandates that major energy consumers employ energy management programs and large consumers report their quarterly energy consumption to the Office of Energy Affairs (OEA). The OEA assists consumers in complying with these requirements by offering a wide range of conservation services, such as an energy management training programs, energy conservation briefings, industry-specific publications, assistance to the Energy Management Associations of the Philippines (a private sector group), consulting and audits, efficiency testing, and industrial monitoring. The Omnibus Energy Conservation Law requires the establishment of standards for energy use in commercial buildings, for construction materials, and for commercial and industrial building plans prior to the issuance of building permits or for adding equipment such as air conditioning units. ${ }^{100}$

Placing electricity rate meters in apartments and factories can also help save energy as owners or tenants can be charged according to their usage, and thus have an incentive to save. Charges should be assessed by the amount of electricity used, not on a square foot basis as is done in Poland, for example. ${ }^{101}$ Appliance energy efficiency standards are now being considered in Jamaica, Thailand, Malaysia, Philippines, Indonesia, and Brazil. ${ }^{102}$

99. OTA, supra note 1 , at 39.

100. OTA, supra note 1 , at 39.

101. Memorandum from Marc Ledbetter of the American Council for an EnergyEfficient Economy to Office of Soviet and East European Affairs, and the U.S. National Academy of Sciences (NAS), re: Trip Report for NAS-sponsored trip to Poland to discuss energy efficiency/environmental issues, October 15-26, 1990. (Nov. 7, 1990).

102. Michael Phillips, International Institute for Energy Conservation, Energy Conservation Activities in Latin America and the Caribbean 28 (1990); Howard S. Geller, American Counch for an Energy-Efficient Economy, Electricity Conservation in Brazil: Status Report and Analysis (1990). 
D. Multilateral Development Bank (MDB) and Industrial Country Practices

\section{Background}

The World Bank and the other Multilateral Development Banks (MDBs) comprise the largest lending source for developing country energy investments, and commercial banks and bilateral financial agencies tend to follow their lead. Their accent on inefficient and polluting supply resources and failure to fund efficiency and renewable resources (except large hydroelectric dams), has enormous impact on the nature of energy investments in the developing world. Most MDB funds are used to promote major developmental projects, such as dams, irrigation systems, and industrial complexes. More than $90 \%$ of international aid designated for energy development is used to construct major electrical generating and transmitting systems, mainly hydropower. However, fewer than $1 \%$ of all energy aid has been used to improve energy efficiency, with the majority applied towards industrial uses. ${ }^{103}$

The banks lack personnel with training and skills for comparing supply and demand-side options. They have no institutional capacity to evaluate the economic and environmental merits of efficiency investments compared to large energy projects. There is a plethora of large companies proposing large projects to them. The more dispersed and smaller efficiency project possibilities just never come to their attention. Even if they did, most projects are so much smaller than supply loans, that they are ignored, regardless of how cost-effective they might be. ${ }^{104}$

The problem is compounded further as sectors within the MDBs are further divided into subsectors. Transportation is treated separately from energy projects, for example, with disastrous energy and environmental consequences. Transportation lending has been overwhelmingly concentrated on road building rather than on vastly less energy-intensive and less polluting mass transit. For example, out of the $\$ 1.8$ billion

103. WRI, supra note 8 , at 18.

104. Totten, supra note 4 , at 8 . 
lent for urban transport between $1972-1988,52 \%$ was used on roads, as opposed to only $9 \%$ for rail systems. The Asian countries spent an average $68 \%$ on roads and only $14 \%$ on public transportation. ${ }^{105}$

Typically, aid has not effectively fostered indigenous technical capability or use of local materials, partly because of the emphasis on large projects for which highly specialized support services are required. Most of the loans and grants managed by international or bilateral organizations are given specifically to cover expenses involving foreign currency. A typical loan covers about one-third of the project cost and is spent mainly on consulting and engineering services and on imported machinery. These practices, which in effect recycle aid back to the donor country, are not conducive to least-cost or to self-reliant development. ${ }^{108} \mathrm{~A}$ major effort, therefore, must be made by the MDBs and the developed country lending and foreign assistance institutions to change their structure and practices so as to foster least-cost and affordable development. Some specific recommendations follow.

\section{Policy Direction \& Structure}

The directors of each MDB and national development agency should establish an announced policy of least-cost investment in developing countries, including financing renewable and energy efficiency technologies and measures where they are the least-cost resource, taking into account the life cycle and system costs of installations and the environmental costs of alternative options. The MDBs and national development agencies should also establish efficiency and renewable departments at a high level within their organizational structures. Personnel in these departments, indeed all loan officers, should be trained in least-cost planning procedures and in the availability and costing procedures for valuing renewable and efficiency technologies and environmental externalities. They should be charged with assisting developing countries in fi- 
nancing equipment, spare parts, training, marketing, implementing and operations, and maintenance of all technologies funded.

\section{Least-Cost Planning}

Just as developing countries should do least-cost energy planning, so too should lending agencies do least-cost planning for their investments, taking into account the life cycle, system, and environmental costs of the technologies financed. This planning process should compare all supply and demand energy options and rank them in order of their costeffectiveness.

MDBs presently analyze only least-cost supply options, utilizing models such as the Wien Automated Systems Model (WASP), an internationally accepted generation capacity expansion planning model, which assumes the power demand as a given. ${ }^{107}$ This supply-oriented bias has to be reversed if affordable energy for development is to be financed by the banks and made possible for developing countries. Power sector loans should require that the program financed be a part of a local country least-cost energy plan.

\section{Non-Energy Project Planning}

Least-cost energy planning should also be required for all non-energy project financing. Loan officers should be required to compare the energy and environmental costs of each project with alternatives. For example, highway projects should be compared to mass transit alternatives, not just on the basis of first costs, but on the basis of the life cycle system costs required to finance the operation of the project, including the costs of manufacture or import and the fuel to run the vehicles that will use the highway. Likewise, incandescent lightbulb plants should be compared to compact fluorescent plants on the same basis and so on.

For transportation lending, a comprehensive, least-cost transportation plan should be required which includes consid- 
eration of all alternative modes of transportation and the utilization of land use planning to minimize motorized transport requirements. Funding should be provided for bicycle manufacturing and purchase.

\section{Renewable \& Efficiency Funding}

Despite the World Bank's new environmental awareness, only about $3 \%$ of its energy and industry loans in 1989 went to improving efficiency of energy use. Renewables other than hydroelectric dams received virtually nothing. The same holds true for other MDBs and national agency programs. As noted above, less than $1 \%$ of all international energy aid has been used to improve energy efficiency. ${ }^{108}$ Multilateral lending for renewables and efficiency at significantly higher levels is essential if least-cost goals for developing countries are to be met.

\section{Program Financing}

Efficiency investments require financing not only for hardware, but also for public education, technical assistance, training, institution-building, marketing, pilot programs where appropriate, and implementation, usually on a door-todoor basis. MDBs and national development agencies, accustomed to funding specific capital intensive projects, should instead think of funding integrated efficiency programs. This should include study tours of other energy systems where least-cost planning is being performed, and the institution of worthwhile efficiency programs.

\section{Regionalization \& Finance Packaging}

Since efficiency and solar technologies (except for solar central station power generating stations) are much less capital-intensive than the supply projects the lending institutions are used to funding, efforts should be made to package financing of appropriate technologies for several countries and over 
an extended period of time.

The lending institutions should assist developing countries in establishing regional centers for research and development, joint purchasing, joint training, and other functions where the cooperation of several countries would assist the economy and chances of success of programs. Such centers should facilitate economic use of lending institution resources, enhance the ability to disseminate solar and efficiency information, permit more economic purchases by developing countries, and facilitate the packaging of larger loan or grant packages.

Regional efficiency and renewables centers of one kind or another have been recommended by virtually every expert that has reviewed developing country energy needs. The former West German Chancellor, Willy Brandt, proposed an International Solar Energy Agency to assist developing countries with research on renewable technologies and construction of production facilities, and promote information and personnel exchanges. ${ }^{109}$ The concept should be broadened to include efficiency technologies as well.

Amulya Reddy of the Department of Management Studies at the Indian Institute of Science has considered a proposal for creation of a broader international energy-efficiency institution, covering promotion of efficiency measures as well as research and development (R\&D), which he calls a Global Energy-Efficiency Mechanism (GEM). ${ }^{110}$

A final report, just issued by the Task Force on International Development and Environmental Security of the Environmental and Energy Study Institute in Washington, D.C., chaired by James Gustave Speth, President of the World Resources Institute, comes to the same conclusion. The report, issued in May 1991, includes as one of its twelve major recom-

109. Flavin, supra note 20, at 38; Eurosolar, Memorandum for the Establishment of an International Solar EnERgy Agency (ISEA) within the United NaTIONS (1990).

110. Amulya Reddy, Global Energy-Efficiency Mechanism (GEM), draft paper for the Department of Management Studies, Indian Institute of Science (undated). The agency would have the mission of providing information, training, analysis, advocacy and action. 
mendations: "Help create a global network of centers for training and research on energy efficiency and renewable energy."111

\section{Research \& Development Priorities}

In 1989, the twenty-one members of the International Energy Agency (IEA) dedicated three-fourths of their combined energy research budgets of $\$ 7.3$ billion to nuclear energy and fossil fuels. The $\$ 883$ million spent on nuclear fusion research in 1989 by these countries is more than worldwide expenditures on efficiency and renewables research. The British government and the European Community are spending $\$ 65$ million for development of a manufacturing process to convert coal to oil, nearly three times the total U.K. spending on renewable energy research in 1989.112

Research and development priorities of the MDBs and other national and international research and funding institutions must be changed to emphasize renewables and efficiency measures. They should assist developing countries in establishing regional research and development facilities focused on renewables and efficiency technologies, recommended above, as a high priority.

Sadly, the R\&D priorities of many developing countries are as askew as those of the multilateral agencies. India, for example, has a huge and costly nuclear research establishment that for three decades has contributed little to the country's energy supply. (The nuclear plants constructed in India have had severe problems. Of India's three nuclear plants, two have experienced high outage rates, while a fourth plant under construction has had delays of seven years.) ${ }^{113}$ India spends less than $1 \%$ of its energy budget on renewable sources (excluding large hydroelectric dams), despite the fact that $40 \%$ of India's

111. Report of an Environmental and Energy Study Institute Task Force on International Development and Environmental Security, Partnership for Sustainable Development: A New U.S. Agenda for International Development and Environmental Security 2, 27-28 (May 1991).

112. Flavin, supra note 20 , at 35,36 .

113. OTA, supra note 1 , at 104. 
energy use comes from renewables. ${ }^{114}$

On the other hand, India has started two very innovative programs for promoting joint $R \& D$ projects, funded by the Indian government and the United States Agency for International Development, to develop technological innovations including energy-efficiency technologies: the Program for Advancement of Commercial Technology (PACT) and the Program to Accelerate Commercial Energy Research (PACER). ${ }^{116}$

9. Energy Supply Priorities - Spare Parts and O \& M Financing

Energy priorities of the international and national lending institutions should emphasize low-capital technologies adaptable to use with indigenous equipment, materials and labor, and requiring minimal life cycle system costs. Nuclear power plants are particularly inappropriate for developing countries because of their high capital costs, great need for foreign capital and experts to maintain them, poor performance, risks of catastrophic accidents like Chernobyl, and the great risks of proliferation.

It has been estimated that to meet half of the developing countries' incremental energy requirements with nuclear energy under the currently used supply strategy projections, 100 large nuclear power plants would have to be built annually between 1985 and 2020. This scenario would place some 3.5 million kilograms $(\mathrm{kg})$ of weapons-usable plutonium in developing countries annually by 2020 . Since a nuclear weapon can be constructed with only 5 to $10 \mathrm{~kg}$ of plutonium, international and national institutions would have to police plutonium production and distribution. ${ }^{116}$ It is particularly important for the International Atomic Energy Agency (IAEA) to reconsider its promotional role for nuclear power, since its programs are aimed principally at developing countries which cannot afford or manage nuclear projects for the most part,

114. Flavin, supra note 20 , at 36 .

115. Jhirad, supra note 97 , at 375 .

116. WRI, supra note 8 , at 6 . 
but get $40 \%$ of their energy from renewables. ${ }^{117}$

Lending institutions should also emphasize improving the performance of existing energy networks in developing countries. These are usually far more economically sound investments than investments in new systems, particularly in light of the huge costs of unreliable existing systems to the developing countries. Deteriorating utility performance and unreliability of delivered power exact a heavy toll on many developing countries. Power supply interruptions have adverse economic effects which range from five to one hundred times the average electric tariff. ${ }^{118}$ Poor levels of plant availability and high transmission and distribution (T\&D) losses have resulted in overbuilding of power supply and maintenance of high capacity reserve margins of up to $40 \% .^{118}$

For example, lost industrial output caused by shortages of electricity in India and Pakistan is estimated to have reduced GDP by about 1.5 to $2 \% .^{120}$ In India, the estimated annual costs of load shedding are equal to 1 to $3 \%$ of GDP. ${ }^{121}$ During a recent five year period, Bombay experienced 1,000 power outages each year. ${ }^{122}$ In China, electricity shortages and disruptions during the 1980 s were responsible for idling at least $20 \%$ of the country's industrial capacity. ${ }^{123}$ Even in areas where power supply is ample, extreme voltage fluctuations occur often, limiting the use of certain equipment. Thus, poor quality and unreliability undermine any economic benefits of electric power in many developing countries. ${ }^{124}$

Investment in spare parts, maintenance, voltage regulation, transmission improvements, operator training and the like can be many times more cost-effective than investments in new supply which will be subject to the same inefficiencies.

117. Flavin, supra note 20 , at 38.

118. Jhirad, supra note 97 , at 372 .

119. Jhirad, supra note 97 , at 376-77.

120. Jhirad, supra note 97 , at 372 .

121. OTA, supra note 1 , at 106.

122. OTA, supra note 1, at 106; Tata Energy Research Institute, Two Strategies for Electric Load Leveling for India, Phase I: Final Report 6 (1987).

123. Vaclav Smil, U.S. Office of Technology Assessment, China's Energy: A Case Study (1990).

124. OTA, supra note 1 , at 106. 
It has been estimated that investments in spare parts and maintenance can be three times more efficient than investments in new supply. ${ }^{125}$ The lending institutions should alter present policies which discourage financing of spare parts and maintenance for all the equipment they finance and supply.

\section{Evaluation}

Evaluation of all programs should begin at the start of all lending programs to assure the collection of adequate baseline data and measurement of results. Evaluation should not be delayed, as is often the present practice, until a program or project is nearly complete.

The World Bank's Energy Sector Management Assistance Program (ESMAP), which assists countries in assessing their energy programs and requirements, needs revision to incorporate end-use efficiency in its surveys and follow up on surveys to assist with implementation. Of the seventy-six countries in which it has recommended energy actions in its assessments, ESMAP issued no efficiency recommendations in thirty-seven of them. Of sixty countries in which it is conducting energy pre-investment and pre-pre-feasibility activites, only seven end-use projects are included. Of about 320 efficiency recommendations made by ESMAP, no more than fifty have been attempted to be implemeted and there is no requirement for documentation of savings. ${ }^{126}$

\section{Lines of Credit}

Dedicated lines of credit should be established for procurement of energy conservation and renewable technologies.

12. Discourage Tied Loans \& Provide Local Seed Money

Loans tied to purchases in the country of the lender discourage self-sufficiency and cause additions to developing

125. Jhirad, supra note 97 , at 381 .

126. Michael Phillips, International Institute for Energy Conservation Working Draft: Alternative Roles for the Energy Sector Management Assistance Program in End-Use Energy Efficiency 1-2 (1990). 
country debt. Also, industrialized country products are often not best suited for indigenous use and may require expensive maintenance and import of spare parts. Plenty of energy export opportunities exist for developed countries without having to resort to the tied loans so prevalent today. Furthermore, seed money should be provided for starting up local energy-efficiency businesses and factories producing energyefficient technologies. Local production and use of local materials and labor are far cheaper to developing countries than imports, promote faster development, conserve foreign exchange, and foster self-sufficiency.

\section{Cooperation Among Lenders}

Too often, different multilateral and bilateral lending agencies finance separate energy related projects in the same country without any coordination of their activities. Sometimes the projects are duplicative or work at cross-purposes. The lack of cooperation leads to inefficient financing. It would be highly advantageous to foster cooperative arrangements among donors to achieve least cost and efficient lending practices. An example of what might be done is demonstrated by the collaborative approach of the Multiagency Working Group on Power Sector Innovation (MAGPI) which was established by donor agencies in a number of countries in cooperation with the World Bank to trouble-shoot the poor performance of power projects they have financed. ${ }^{127}$

Another effective model of donor collaboration is provided by the Consultative Group on International Agricultural Research (CGIAR). CGIAR involves research programs and related activities that are funded by some forty donors, both public and private. ${ }^{128}$

E. Institution of an International Carbon Tax

There has been much discussion of an international carbon tax. It is time to institute one. In January 1991, Sweden 
put into effect an internal carbon tax of about $\$ 160$ per ton of carbon emitted, while reducing other existing energy taxes by $50 \% .^{128}$ Carbon taxes took effect in Finland in January 1990 and the Netherlands in January 1991 and are under consideration in Germany, Norway, and Switzerland. ${ }^{130} \mathrm{~A}$ study by the U.S. Congressional Budget Office has found that a slowly phased-in carbon tax of $\$ 110$ per ton of carbon' emmitted would reduce carbon emissions in the United States by $27 \%$ from 1988 levels by the year 2000, with less than a $1 \%$ reduction in the nation's economic output that year. ${ }^{131}$

Many countries have expressed concern, however, that imposing a substantial national carbon tax would put them at a competitive disadvantage in relation to countries that did not impose such a tax. Therefore, there has been serious consideration of an international carbon tax proposal. Geller has calculated that a very modest worldwide tax of $\$ 8$ per metric ton of carbon emitted from burning fossil fuels would be equivalent to about $\$ 1$ per barrel of oil, $\$ 5.50$ per metric ton of coal and $\$ 4.20$ per thousand cubic meters of natural gas. The tax would generate nearly $\$ 50$ billion per year in tax revenue, but somewhat less if the poorest nations were exempt. It would have a minor impact on energy prices, raising them by about $2 \%$ in the United States. If a portion of the tax were used for energy-efficiency improvements, the tax could have a positive net impact on national economies. Geller recommends that the proceeds be used to mount a global energy-efficiency campaign implemented through an international energy-efficiency agency. ${ }^{132}$

However, the tax, even at this modest level, would start the process of internalizing the environmental costs of pollution from burning fossil fuels and would create an incentive

129. Howard S. Geller, Establishing an International Energy Efficiency Agency: A Response to the Threat of Global Climate Change, 19 ENERgY PoL. 689, (April 1991) [hereinafter Climate Change].

130. Flavin, supra note 20 , at 29.

131. Flavin, supra note 20, at 30; U.S. Congressional Budget Office, Carbon Charges as a Response to Global Warming: The Efrects of Taxing Fossil, Fuels (August 1990).

132. Flavin, supra note 20 , at 3-4. 
for businesses around the world to invest in more environmentally benign resources. It would send an important signal to polluters that eventually the societal costs of their pollution will be charged to them. An international carbon tax could also provide some of the substantial funds that will be needed (which Geller estimates at $\$ 130$ billion per year in order to cut primary energy use in 2010 by nearly one-third), ${ }^{133}$ but save developing countries four to five times what they otherwise would require to support development to industrial country levels.

\section{Conclusion}

The task of furnishing the energy necessary to achieve high standards of living in developing countries while preserving the world environment is formidable. The capital requirements are immense and the institutional changes required by all involved parties are considerable. With adequate will, the goals are achievable. The consequences of failure would be far more painful than the costs of achievement.

\section{Acknowledgements}

This paper could not have been written without the invaluable research in energy and environment in developing countries performed and published by a number of outstanding experts from around the world, some of whom I have never met. I could do no original research for this project. The paper draws heavily on their fine work.

My deep appreciation goes to Samuel F. Baldwin, Senior Analyst.at the U.S. Office of Technology Assessment; Deborah Lynn Bleviss, Executive Director; Michael Totten, Senior Associate for Policy, and Michael Philips of the International Institute for Energy Conservation; Howard S. Geller, Executive Director of the American Council for an Energy-Efficient Economy; Christopher Flavin and Nicholas Lenssen of the Worldwatch Institute; Jose Goldemberg, Secretary for Science and Technology of Brazil; David Jhirad of the U.S. Agency for

133. Climate Change, supra note 129 , at 693. 
International Development; James Gustave Speth, President, and Mark Kosmo of the World Resources Institute; Mark D. Levine, Ashok Gadgil, Steven Meyers, and Jayant Sathaye of Lawrence Berkeley Laboratory; Jack Stafurik of RCG/Hagler, Bailly, Inc.; Tom Wilbanks of Oak Ridge National Laboratory; Jose R. Moreira of the University of Sao Paulo; Tomas B. Johansson of Sweden; Amulya K. Reddy of the Indian Institute of Science in Bangalore; and Robert H. Williams of the Princeton University Center for Energy and Environmental Studies. Several gave their kind permission to use materials from their studies. 